ISSN: 2302-8556

E-Jurnal Akuntansi Universitas Udayana

Vol.22.2. Februari (2018): 1503-1529

DOI: https://doi.org/10.24843/EJA.2018.v22.i02.p25

\title{
Pengaruh Pengetahuan Perpajakan, Kesadaran dan Pengetahuan Tax Amnesty Pada Kepatuhan WPOP di KPP Pratama Gianyar
}

\author{
Ni Kadek Intania Kesumasari ${ }^{1}$ \\ Ketut Alit Suardana ${ }^{2}$
}

${ }^{1}$ Fakultas
Ekonomi dan Bisnis Universitas Udayana (Unud), Bali, Indonesia
email: kadekintania@gmail.com/Telp: +6281238002223

\begin{abstract}
ABSTRAK
Penelitian ini bertujuan untuk mengetahui pengaruh pengetahuan perpajakan, kesadaran, dan pengetahuan tax amnesty pada kepatuhan wajib pajak orang pribadi. Penelitian ini dilakukan di Kantor Pelayanan Pajak (KPP) Pratama Gianyar. Penelitian ini menggunakan rumus Slovin untuk menentukan jumlah sampel sebanyak 100 wajib pajak orang pribadi yang terdaftar di KPP Pratama Gianyar, dengan metode accidental sampling. Pengumpulan data dilakukan melalui kuesioner. Teknik analisis yang digunakan adalah regresi linier berganda. Hasil penelitian menunjukkan bahwa pengetahuan perpajakan, kesadaran, dan pengetahuan tax amnesty berpengaruh positif pada kepatuhan wajib pajak orang pribadi. Pengetahuan perpajakan, kesadaran, dan pengetahuan tax amnesty mempengaruhi kepatuhan wajib pajak orang pribadi sebesar $77,1 \%$, sedangkan sisanya $22,9 \%$ dipengaruhi oleh variabel lain yang tidak dimasukkan kedalam model penelitian.

Kata kunci : Perpajakan, kesadaran, pengetahuan tax amnesty dan kepatuhan wajib pajak.
\end{abstract}

\begin{abstract}
This study aims to determine the effect of knowledge taxation, awareness, and knowledge of tax amnesty on the compliance of individual taxpayers. This research was conducted at Tax Office (KPP) Pratama Gianyar. This study uses Slovin formula to determine the number of samples as many as 100 individual taxpayers registered in KPP Pratama Gianyar, by accidental sampling method. The data were collected through questionnaires. The analysis technique used is multiple linear regression. The results showed that knowledge of taxation, awareness, and knowledge of tax amnesty have a positive effect on the taxpayer compliance of individuals. Knowledge of taxation, awareness, and knowledge of tax amnesty affect personal taxpayer compliance of $77.1 \%$, while the remaining $22.9 \%$ is influenced by other variables not included in the research model.
\end{abstract}

Keyword : Taxation, awareness, knowledge of tax amnesty and compulsory obedience.

\section{PENDAHULUAN}

Indonesia dilihat selama periode pemerintahan Presiden Joko Widodo (Jokowi)

pemerintah menekankan pada pembangunan infrastruktur di Indonesia, mulai dari

pembangunan jalan tol, pelabuhan, hingga Pos Lintas Batas Negara (PLBN). Seluruh 
pembangunan infrastruktur tersebut tidak terlepas dari pajak yang dibayarkan oleh masyarakat Indonesia. Semakin banyak pajak yang dibayarkan maka semakin banyak infrastruktur yang dibangun. Karena itu, pajak merupakan ujung tombak pembangunan sebuah negara. Kanghua Zeng et al. (2013) reformasi pajak akan mendorong peningkatan penerimaan pajak.

Menurut Undang-undang Nomor 28 tahun 2007 Pasal 1 Tentang Ketentuan Umum dan Perpajakan, Pajak merupakan suatu konstribusi wajib kepada negara yang terhutang oleh setiap orang maupun badan yang sifatnya memaksa namun tetap berdasarkan pada Undang-Undang, dan tidak mendapat imbalan secara langsung serta digunakan untuk kebutuhan negara juga kemakmuran rakyatnya. Diantara sumber pendapatan lainnya pajak adalah penyumbang pendapatan negara paling besar (Munari, 2005). Dalam rangka menyukseskan pembangunan nasional, pajak juga menjadi sektor yang potensial. Berdasarkan data dari Kementrian Keuangan Republik Indonesia, jumlah pendapatan negara terbesar berasal dari sektor pajak. Hal tersebut dapat dilihat pada Tabel 1 tentang realisasi perbandingan jumlah penerimaan negara yang berasal dari pajak dan jumlah penerimaan negara yang bukan berasal dari pajak.

\section{Tabel 1.}

\section{Realisasi Penerimaan Negara (Triliun Rupiah), Tahun 2012 - 2016}

\begin{tabular}{cccc}
\hline Tahun & Penerimaan Pajak & Penerimaan Bukan Pajak & Total \\
\hline 2012 & 980,5 & 351,8 & $1.332,3$ \\
2013 & $1.148,4$ & 349,2 & $1.497,6$ \\
2014 & $1.280,4$ & 385,4 & $1.665,8$ \\
2015 & $1.489,3$ & 269,1 & $1.758,4$ \\
2016 & $1.546,7$ & 273,8 & $1.820,5$ \\
\hline
\end{tabular}

Sumber: www.kemenkeu.go.id, 2017 
ISSN: 2302-8556

E-Jurnal Akuntansi Universitas Udayana

Vol.22.2. Februari (2018): 1503-1529

Berdasarkan Tabel 1 menunjukkan bahwa penerimaan dari sektor pajak lebih besar dibandingkan penerimaan dari sektor non pajak. Hal tersebut membuktikan bahwa kontribusi pajak sangat signifikan dan terus meningkat dari tahun ke tahun sebagai sumber penerimaan negara.

Masyarakat dan pemerintah memiliki pekerjaan dan tanggungjawab dalam pemenuhan pembayaran pajak. Iuran rakyat ini merupakan sumber penerimaan negara yang dapat mewujudkan kesejahteraan bangsa, sehingga sangat diharapkan adanya kepatuhan, kesadaran, dan rasa kepedulian. Permasalahan sering kali timbul dalam pemungutan pajak, yaitu seperti rasa keadilan dan kepastian dalam perumusan kebijakan serta pelaksanaannya. Pemerintah berusaha untuk melakukan pengawasan, menganalisis, mengkaji, dan menyempurnakan administrasi perpajakan sehingga dapat menuju kearah pelayanan pajak yang lebih baik. Adanya suatu sistem perpajakan dalam pemungutan pajak yang sederhana terkait perhitungan, penyetoran, dan pelaporannya diharapkan kemauan membayar oleh wajib pajak menjadi lebih meningkat.

Usaha memaksimalkan penerimaan pajak tidak dapat hanya mengandalkan peran dari pemerintah dalam hal ini Dirjen Pajak maupun petugas pajak, tetapi dibutuhkan juga peran aktif dari para wajib pajak itu sendiri. Kepercayaan wajib pajak untuk mendaftar, menghitung, membayar dan melaporkan kewajiban perpajakannya sendiri diberikan sebagai perubahan sistem perpajakan dari Official 
Assessment menjadi Self Assessment. Hal ini menjadi faktor yang sangat penting dalam menjadikan kepatuhan dan kesadaran wajib pajak untuk mencapai keberhasilan penerimaan pajak (Arum, 2012). Adanya peran aktif dari masyarakat dalam pemenuhan kewajiban perpajakan merupakan tuntutan dari penerapan Self Assessment System. Harahap (2004) dalam Supadmi (2010) menyatakan perubahan sikap (kesadaran) warga masyarakat untuk membayar pajak secara sukarela (voluntary compliance) merupakan misi dan konsekuensi diterapkannya sistem Self Assessment. Tulang punggung dari Self Assessment System yaitu kepatuhan memenuhi kewajiban pajak secara sukarela (Noor, 2013).

Kekhawatiran masyarakat dan wajib pajak dalam membayar pajak timbul karena melihat fenomena kasus-kasus perpajakan yang terjadi di Indonesia belakangan ini. Kepatuhan wajib pajak sangat dipengaruhi oleh kondisi tersebut karena para wajib pajak tidak ingin adanya penyalahgunaan yang dilakukan aparat pajak itu sendiri atas pajak yang telah dibayarkan oleh wajib pajak, sehingga hal tersebut membuat masyarakat dan wajib pajak berusaha menghindari pajak.

Direktorat Jenderal Pajak (DJP) dalam melaksanakan program pelayanan pajak di masing-masing daerah dibantu oleh Kantor Pelayanan Pajak sebagai instansi yang berkewajiban untuk memfasilitasi dan memberikan informasi yang memadai kepada wajib pajak. Tabel 2 menunjukkan data jumlah Wajib Pajak yang terdaftar di Kantor Wilayah DJP Bali Tahun 2016. 
ISSN: 2302-8556

E-Jurnal Akuntansi Universitas Udayana

Vol.22.2. Februari (2018): 1503-1529

Tabel 2.

Data jumlah Wajib Pajak yang terdaftar di Kantor Wilayah DJP Bali Tahun 2016

\begin{tabular}{clr}
\hline No & Tahun & Wajib Pajak yang Terdaftar \\
\hline 1 & KPP Pratama Denpasar Barat & 103,734 \\
2 & KPP Pratama Singaraja & 73,300 \\
3 & KPP Pratama Denpasar Timur & 101,332 \\
4 & KPP Madya Denpasar & 1,504 \\
5 & KPP Pratama Badung Selatan & 61,705 \\
6 & KPP Pratama Badung Utara & 62,792 \\
7 & KPP Pratama Gianyar & 144,700 \\
8 & KPP Pratama Tabanan & 99,854 \\
\hline
\end{tabular}

Sumber: Kantor Wilayah Direktorat Jenderal Pajak Bali (2017)

Data Tabel 2 menunjukkan bahwa Wajib Pajak terdaftar di KPP Pratama

Gianyar paling besar diantara seluruh KPP di Provinsi Bali yaitu 144,700 Wajib

Pajak. Meskipun jumlah wajib pajak yang terdaftar besar, namun terdapat kendala yang dapat menghambat keefektifan pengumpulan pajak. Kendala tersebut adalah kepatuhan wajib pajak (tax compliance). Berikut ini tingkat kepatuhan pelaporan Surat Pemberitahuan (SPT) tahunan Wajib Pajak Orang Pribadi di Kantor Pelayanan Pajak Pratama Gianyar dapat dilihat dari Tabel 3.

\section{Tabel 3.}

\begin{tabular}{ccccc}
\multicolumn{5}{c}{ Tingkat Kepatuhan Wajib Pajak Orang Pribadi di KPP Pratama Gianyar } \\
Tahun 2013-2016
\end{tabular}

Sumber: KPP Pratama Gianyar (2017). 
Pada Tabel 3 dapat dilihat jumlah WPOP terdaftar mengalami peningkatan namun kepatuhan WPOP di lingkungan KPP Pratama Gianyar mengalami fluktuasi selama tahun 2013-2016. Persentase kepatuhan WPOP pada tahun 2013 sebesar 59 persen mengalami peningkatan yaitu 61 persen pada tahun 2014 dan 69 persen pada tahun 2015. Namun, pada tahun 2016 tingkat kepatuhan WPOP mengalami penurunan yaitu 68 persen. Berdasarkan data tersebut, maka penelitian ini dilakukan di KPP Pratama Gianyar. KPP Pratama Gianyar merupakan salah satu instansi vertikal di lingkungan Kantor Wilayah Direktorat Jenderal Pajak Bali yang wilayah kerjanya meliputi empat kabupaten yaitu, Gianyar, Bangli, Klungkung, dan Karangasem.

Sebagai instansi yang berkewajiban memberikan fasilitas serta informasi yang memadai bagi para wajib pajak, KPP Pratama Gianyar melalui peningkatan pengetahuan perpajakan. Pengetahuan sangat penting dalam membantu wajib pajak dalam melaksanakan kewajibannya. Seorang wajib pajak harus terlebih dahulu mengetahui apa yang menjadi kewajibannya. Pada penelitian Palil dan Musthapa (2011), Putri (2015) dan Ulfa (2015) mengenai faktor-faktor yang mempengaruhi kepatuhan wajib pajak bahwa pengetahuan perpajakan memberikan pengaruh positif dan signifikan terhadap kepatuhan wajib pajak. Namun berbeda dengan hasil penelitian Hardiningsih (2011) bahwa pengetahuan peraturan perpajakan tidak berpengaruh terhadap kemauan membayar pajak.

Selain Pengetahuan Perpajakan, Kesadaran wajib pajak dalam membayar 
ISSN: 2302-8556

E-Jurnal Akuntansi Universitas Udayana Vol.22.2. Februari (2018): 1503-1529

kewajibannya merupakan hal penting dalam penerimaan pajak. Peningkatan penerimaan pajak negara akan terjadi jika adanya kesadaran wajib pajak akan peraturan perpajakan dan kewajiban pajaknya. Ali et al. (2001) menyatakan bahwa sanksi merupakan kebijakan efektif untuk mencegah ketidakpatuhan wajib pajak. Diperlukan kesadaran masyarakat dengan mengoptimalkan semua potensi dan sumber daya yang ada untuk memenuhi kebutuhan penerimaan pajak yang terus meningkat. Penelitian terdahulu mengenai kesadaran wajib pajak, Muliari dan Ery (2009) mengemukakan bahwa kesadaran wajib pajak berpengaruh positif pada kepatuhan wajib pajak. Hal tersebut sejalan dengan hasil penelitian Lovihan (2014) dan Agung Mas (2014).

Selain Pengetahuan Perpajakan dan Kesadaran, Pengetahuan Tax Amnesty juga diperlukan untuk menambah pengetahuan terhadap kepatuhan wajib pajak mengikuti tax amnesty. Tax Amnesty merupakan salah satu kebijakan dibidang perpajakan yang dilaksanakan oleh Dirjen Pajak. Pengampunan Pajak atau Tax Amnesty adalah penghapusan pajak yang seharusnya terutang, tidak dikenai sanksi administrasi perpajakan dan sanksi pidana di bidang perpajakan, dengan cara mengungkap harta dan membayar uang tebusan sebagaimana diatur dalam UndangUndang Nomor 11 Tahun 2016 tentang Pengampunan Pajak. Amnesti juga sering disertai dengan peningkatan upaya administrasi pajak, terutama dalam langkahlangkah penegakan (James Alm, et al. 2009). Pada Tabel 4 menunjukkan jumlah Wajib Pajak yang telah mengikuti Tax Amnesty sebanyak 4,038 orang, yang terdiri 
dari 714 Wajib Pajak Badan dan 3,324 Wajib Pajak Orang Pribadi. Jumlah WPOP yang mengikuti Tax Amnesty mencapai 82,31\% dari keseluruhan wajib pajak ikut serta. Hal ini menunjukan timbulnya kesadaran wajib pajak dalam mengungkapkan harta yang belum diungkapkan dalam SPT, kemudian menebus sesuai dengan jumlah yang ditentukan. Jika di bandingkan dengan jumlah WPOP terdaftar tahun 2016 pada Tabel 3 menunjukkan, WPOP yang sudah mengikuti Tax Amnesty sebanyak 2,41\% dari jumlah WPOP terdaftar.

Tabel 4.

Wajib Pajak yang Mengikuti Tax Amnesty di KPP Pratama Gianyar Tahun 2016

\begin{tabular}{ccc}
\hline Wajib pajak & Jumlah & \% \\
\hline Badan & 714 & 17,68 \\
Pribadi & 3,324 & 82,31 \\
\hline Jumlah & 4,038 & 100 \\
\hline
\end{tabular}

Sumber: KPP Pratama Gianyar (2017).

Tujuan dari pengampunan pajak adalah untuk meningkatkan penerimaan pajak (UU No.11 Tahun 2016). Selain itu untuk mempercepat pertumbuhan dan restrukturisasi ekonomi melalui pengalihan harta, yang akan berdampak pada peningkatan likuiditas domestik, perbaikan nilai tukar Rupiah, penurunan suku bunga, dan peningkatan investasi. Penelitian terdahulu oleh Ngadiman dan Huslin (2015), dan Suyanto (2016) menunjukkan bahwa tax amnesty berpengaruh positif dan signifikan terhadap kepatuhan wajib pajak. Namun penelitian Alm (1998) menunjukkan bahwa tingkat kepatuhan jatuh setelah adanya program tax amnesty.

Tujuan yang ingin di capai dalam penelitian ini adalah memahami dan menganalisis pengaruh pengetahuan perpajakan pada kepatuhan wajib pajak orang 
ISSN: 2302-8556

E-Jurnal Akuntansi Universitas Udayana

Vol.22.2. Februari (2018): 1503-1529

pribadi di KPP Pratama Gianyar, memahami dan menganalisis pengaruh kesadaran pada kepatuhan wajib pajak orang pribadi di KPP Pratama Gianyar dan memahami dan menganalisis pengaruh pengetahuan tax amnesty pada kepatuhan wajib pajak orang pribadi di KPP Pratama Gianyar.

Kegunaan penelitian ini adalah bagi bidang pengetahuan penelitian ini diharapkan dapat memperluas pengetahuan dan wawasan bagi mahasiswa serta dapat digunakan sebagai bahan masukan bagi peneliti lain yang mengadakan penelitian dalam ruang lingkup yang sama mengenai pengaruh pengetahuan perpajakan, kesadaran dan pengetahuan tax amnesty pada kepatuhan wajib pajak orang pribadi dan bagi pemerintah penelitian ini diharapkan dapat memberikan informasi dan masukan yang dibutuhkan mengenai pengaruh pengetahuan perpajakan, kesadaran dan pengetahuan tax amnesty pada kepatuhan wajib pajak orang pribadi, agar nantinya dapat memberikan manfaat bagi Direktur Jenderal Pajak di Indonesia untuk kepatuhan Wajib Pajak Orang Pribadi dalam melaksanakan kewajiban pembayaran pajak.

Pengetahuan perpajakan dalam teori atribusi, merupakan salah satu faktor eksternal yang dapat mempengaruhi prilaku kepatuhan wajib pajak dalam membayar pajak. Sedangkan dalam teori pengambilan keputusan bertujuan untuk mengetahui manfaat dari pengetahuan perpajakan. Pengetahuan perpajakan merupakan pemahaman Wajib Pajak mengenai hukum, undang-undang, tata cara perpajakan 
yang benar. Dengan adanya pengetahuan tentang pajak yang baik akan dapat memperkecil adanya tax evation (Banu, 2008).

Pada penelitian yang dilakukan oleh Palil dan Musthapa (2011), menyatakan bahwa ketika seseorang wajib pajak memiliki pengetahuan perpajakan yang baik, sikap terhadap pajak akan lebih positif dan dapat meningkatkan kepatuhan dan mengurangi kecurangan menghindari pajak. Sejalan dengan penelitian Putri (2015) dan Ulfa (2015) menunjukkan bahwa pengetahuan pajak memberikan pengaruh signifikan terhadap kepatuhan wajib pajak. Namun berbeda dengan hasil penelitian Hardiningsih (2011) bahwa pengetahuan peraturan perpajakan tidak berpengaruh terhadap kemauan membayar pajak. Maka dari penjelasan diatas dapat membangun hipotesis dalam penelitian ini adalah :

$\mathrm{H}_{1}$ : Pengetahuan perpajakan berpengaruh positif pada kepatuhan wajib pajak orang pribadi.

Theory of Planned Behavior (TPB) menjelaskan bahwa perilaku yang ditimbulkan oleh individu muncul karena adanya niat untuk berperilaku, hal tersebut berkaitkan dengan kesadaran wajib pajak. Menurut Suryadi (2006), kesadaran wajib pajak akan meningkat jika masyarakat memiliki persepsi positif tentang pajak. Dengan meningkatkan pengetahuan perpajakan dalam masyarakat melalui pengetahuan perpajakan, baik formal maupun informal akan memberikan dampak positif pada kesadaran wajib pajak untuk membayar pajak.

Palil (2005) juga menyatakan bahwa pengetahuan pajak merupakan salah satu hal penting dalam meningkatkan kesadaran wajib pajak untuk membayar pajak. 
ISSN: 2302-8556

E-Jurnal Akuntansi Universitas Udayana

Vol.22.2. Februari (2018): 1503-1529

Beberapa penelitian sebelumnya yang dilakukan oleh Muliari dan Ery (2009) mengemukakan bahwa kesadaran wajib pajak berpengaruh positif pada kepatuhan wajib pajak. Hal tersebut sejalan dengan hasil penelitian Lovihan (2014) dan Agung Mas (2014). Berdasarkan hasil penelitian terdahulu, maka hipotesis dalam penelitian ini adalah :

$\mathrm{H}_{2}$ : Kesadaran berpengaruh positif pada kepatuhan wajib pajak orang pribadi.

Dalam teori pengembilan keputusan, penelitian ini bertujuan adanya pemahaman wajib pajak tentang manfaat pengetahuan tax amnesty. Sedangkan pengetahuan tax amnesty dalam teori atribusi, merupakan salah satu faktor eksternal yang dapat mempengaruhi prilaku kepatuhan wajib pajak dalam membayar pajak. Dalam penelitian ini Andreoni (1991) mengatakan bahwa tax amnesty berpengaruh dalam meningkatkan pembayaran pajak dan kepatuhan pajak. Darusalam (2011) mengatakan bahwa tax amnesty diperlukan untuk menarik kelompok masyarakat yang belum masuk ke dalam sistem administrasi perpajakan untuk masuk dan menjadi bagian dari sistem administrasi perpajakan sehingga dapat berperan dalam pembagunan negara. Begitu juga Ngadiman dan Huslin (2015), dan Suyanto (2016) menunjukkan bahwa tax amnesty berpengaruh positif dan signifikan terhadap kepatuhan wajib pajak. Namun penelitian Alm (1998) menunjukkan bahwa tingkat kepatuhan jatuh setelah adanya program tax amnesty. Berdasarkan hasil penelitian terdahulu, maka hipotesis dalam penelitian ini adalah : 
$\mathrm{H}_{3}$ : Pengetahuan tax amnesty berpengaruh positif pada kepatuhan wajib pajak orang pribadi.

\section{METODE PENELITIAN}

Pendekatan kuantitatif berbentuk asosiatif merupakan pendekatan yang digunakan dalam penelitian ini. Desain penelitian sebagai berikut:

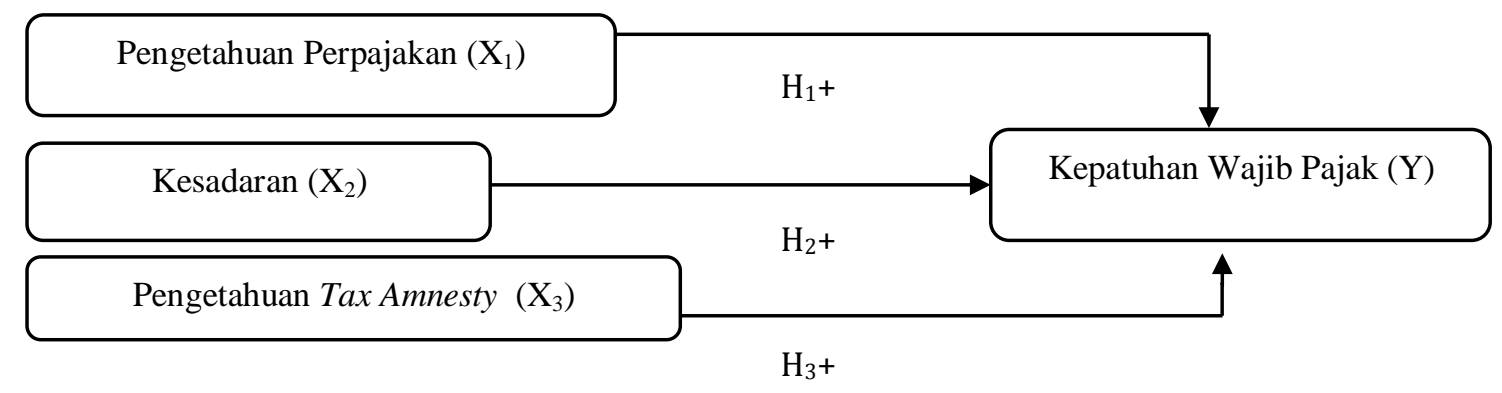

Gambar 1. Desain Penelitian

Sumber: Data diolah, 2017

Penelitian ini dilakukan di Kantor Pelayanan Pajak (KPP) Pratama Gianyar yang beralamat di Jalan Dharma Giri Blahbatuh, Gianyar. Alasan memilih lokasi di KPP Pratama Gianyar, karena wilayah kerjanya meliputi empat kabupaten yaitu Gianyar, Bangli, Klungkung, dan Karangasem. Berdasarkan data Tabel 2 menunjukkan bahwa Wajib Pajak terdaftar di KPP Pratama Gianyar paling banyak diantara seluruh KPP di Provinsi Bali. Peneliti tertarik untuk meneliti faktor-faktor yang mempengaruhi kepatuhan Wajib Pajak Orang Pribadi.

Obyek penelitian adalah suatu sifat dari obyek yang diterapkan oleh peneliti untuk dipelajari dan kemudian memperoleh kesimpulan (Sugiyono, 2017:38). Obyek dalam penelitian ini adalah kepatuhan Wajib Pajak Orang Pribadi pada KPP Pratama 
ISSN: 2302-8556

E-Jurnal Akuntansi Universitas Udayana

Vol.22.2. Februari (2018): 1503-1529

Gianyar, khususnya mengenai pengetahuan perpajakan, kesadaran dan pengetahuan tax amnesty. Variabel bebas dalam penelitian ini adalah Pengetahuan Perpajakan $\left(\mathrm{X}_{1}\right)$, Kesadaran $\left(\mathrm{X}_{2}\right)$, Pengetahuan Tax Amnesty $\left(\mathrm{X}_{3}\right)$ sedangkan variabel terikat dalam penelitian ini adalah Kepatuhan Wajib Pajak (Y).

Jenis data yang digunakan dalam penelitian ini dapat dibagi menjadi dua yaitu Data kualitatif adalah data yang dinyatakan dalam bentuk kata, kalimat, dan skema (Sugiyono, 2017:7). Data kualitatif dalam penelitian ini adalah daftar pernyataanpernyataan yang terdapat dalam kuesioner, gambaran umum, sejarah, serta struktur organisasi KPP Pratama Gianyar. Data kuantitatif adalah data dalam bentuk angka yang dapat dinyatakan dan diukur dengan satuan hitung atau merupakan data kuantitatif yang ditingkatkan (Sugiyono, 2017:7). Data kuantitatif dalam penelitian ini adalah data jumlah Wajib Pajak yang terdaftar di Kantor Wilayah DJP Bali Tahun 2016 dan di KPP Pratama Gianyar, data Realisasi Penerimaan Negara, data jumlah wajib pajak mengikuti Tax Amnesty, serta jawaban dari pertanyaan-pertanyaan kuesioner yang telah dikuantitatifkan.

Sumber data dalam penelitian ini adalah data primer yaitu data penelitian yang langsung diberikan data pada pengumpul data (Sugiyono, 2017:137). Data diperoleh dari jawaban Wajib Pajak yang berada pada KPP Pratama Gianyar, yaitu jawaban terhadap serangkaian pertanyaan kuesioner yang diajukan dari peneliti mengenai faktor-faktor yang mempengaruhi kepatuhan pajak sedangkan data sekunder adalah data penelitian yang langsung diberikan data pada pengumpul data (Sugiyono, 
2017:137). Data diperoleh dari jawaban Wajib Pajak yang berada pada KPP Pratama Gianyar, yaitu jawaban terhadap serangkaian pertanyaan kuesioner yang diajukan dari peneliti mengenai faktor-faktor yang mempengaruhi kepatuhan pajak.

Populasi adalah wilayah generalisasi yang terdiri atas objek atau subjek yang mempunyai kualitas dan karakteristik tertentu yang ditetapkan oleh peneliti untuk dipelajari dan kemudian ditarik kesimpulannya (Sugiyono, 2017:80). Populasi dalam penelitian ini adalah seluruh Wajib Pajak Orang Pribadi yang terdaftar di KPP Pratama Gianyar. Metode penentuan sampel yang digunakan adalah non probability sampling yaitu teknik pengambilan sampel yang tidak memberikan peluang atau kesempatan sama bagi setiap unsur atau anggota populasi untuk dipilih menjadi sampel. Teknik yang digunakan adalah accidental sampling, yaitu dengan cara ini peneliti dapat memilih orang-orang yang dekat dengannya atau memilih responden yang pertama kali berhasil dijumpai (Rahyuda, dkk. 2004:51). Penentuan jumlah sampel dirumuskan dengan rumus Slovin. Perumusan dirumuskan sebagai berikut:

$$
\mathrm{n}=\frac{\mathrm{N}}{\mathrm{ni} e^{2}+1}
$$

Dimana :

$\mathrm{n}=$ Jumlah sampel

$\mathrm{N}=$ Ukuran Populasi

$\mathrm{e}=$ Batas kesalahan $(10 \%)$

Berdasarkan data dari KPP Pratama Gianyar, diketahui jumlah populasi dari seluruh Wajib Pajak Orang Pribadi Terdaftar Tahun 2016 adalah sebanyak 137.649 orang. Dengan menggunakan rumus Slovin, besarnya sampel penelitian ini adalah: 
ISSN: 2302-8556

E-Jurnal Akuntansi Universitas Udayana

Vol.22.2. Februari (2018): 1503-1529

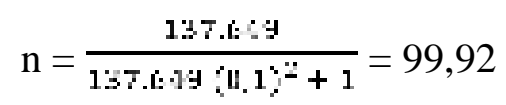

Banyaknya sampel yang diambil pada penelitian ini adalah sebanyak 99,92 yang dibulatkan menjadi 100 Wajib Pajak Orang Pribadi.

Metode pengumpulan data dilakukan dengan dua cara, yaitu Metode kuesioner ini dilakukan dengan memberikan kuesioner kepada responden. Pemberian kuesioner dapat dilakukan dengan memberikan secara langsung kepada responden dengan syarat sebagai WPOP yang terdaftar di KPP Pratama Gianyar. Jawabanjawaban responden diberi nilai/skor menggunakan skala Likert. Observasi nonpartisipan yaitu teknik pengumpulan data dimana peneliti tidak terlibat dan hanya sebagai pengamat independen (Sugiyono, 2017:146). Peneliti mengamati, mengumpulkan data dari dokumen perusahaan berupa sejarah berdirinya, struktur organisasi, dan uraian tugas masing-masing bagian pada KPP Pratama Gianyar.

Teknik analisis data yang digunakan adalah analisis regresi linier berganda. Analisis model berganda dilakukan untuk mengetahui pengaruh antar variabel terikat dan variabel bebas dengan bantuan SPSS for Windows. Model regeresi linear berganda ditunjukan sebagai berikut :

$$
\begin{aligned}
& Y=\alpha+\beta_{1} X_{1+} \beta_{2} X_{2+} \beta_{3} X_{3}+\varepsilon \\
& \text { Keterangan : } \\
& \text { Y : Kepatuhan Wajib Pajak } \\
& \alpha \quad \text { : Konstanta } \\
& \mathrm{X}_{1} \quad \text { : Pengetahuan Perpajakan } \\
& \mathrm{X}_{2} \quad \text { : Kesadaran } \\
& \mathrm{X}_{3} \text { : Pengetahuan Tax Amnesty } \\
& \beta_{1} \text { : Koefisien regresi variable } X_{1}
\end{aligned}
$$


$\beta_{2}$ : Koefisien regresi variable $X_{2}$

$B_{3} \quad$ : Koefisien regresi variable $X_{3}$

$\varepsilon \quad:$ Error

\section{HASIL DAN PEMBAHASAN}

Menurut Sugiyono (2017:125) instrumen yang valid adalah alat ukur yang digunakan untuk mendapatkan data (mengukur) tersebut valid. Hal ini dilakukan dengan mencari korelasi dari setiap item pertanyaan dengan skor total pertanyaan untuk hasil jawaban responden yang mempunyai skala pengukuran ordinal. Pengujian validitas ini menggunakan korelasi product moment. Apabila skor total diatas 0,30 maka keusioner tersebut dikatakan valid. Hasil uji validitas dapat dilihat pada Tabel 5.

Tabel 5.

Hasil Uji Validitas

\begin{tabular}{|c|c|c|c|c|}
\hline No & Variabel & $\begin{array}{c}\text { Kode } \\
\text { Instrumen }\end{array}$ & $\begin{array}{c}\text { Koefisien } \\
\text { Korelasi }\end{array}$ & Keterangan \\
\hline \multirow[t]{5}{*}{1} & Pengetahuan Perpajakan (X1) & $\mathrm{X} 1.1$ & 0,828 & Valid \\
\hline & & $\mathrm{X} 1.2$ & 0,793 & Valid \\
\hline & & $\mathrm{X} 1.3$ & 0,750 & Valid \\
\hline & & $\mathrm{X} 1.4$ & 0,769 & Valid \\
\hline & & $\mathrm{X} 1.5$ & 0,687 & Valid \\
\hline \multirow[t]{5}{*}{2} & Kesaaran (X2) & $\mathrm{X} 2.1$ & 0,751 & Valid \\
\hline & & $\mathrm{X} 2.2$ & 0,751 & Valid \\
\hline & & $\mathrm{X} 2.3$ & 0,668 & Valid \\
\hline & & X2.4 & 0,790 & Valid \\
\hline & & $\mathrm{X} 2.5$ & 0,777 & Valid \\
\hline \multirow[t]{4}{*}{3} & Pengetahuan Tax Amnesty (X3) & X3.1 & 0,848 & Valid \\
\hline & & $\mathrm{X} 3.2$ & 0,834 & Valid \\
\hline & & X3.3 & 0,788 & Valid \\
\hline & & X3.4 & 0,785 & Valid \\
\hline \multirow[t]{5}{*}{4} & Kepatuhan Wajib Pajak (Y) & Y.1 & 0,803 & Valid \\
\hline & & Y.2 & 0,734 & Valid \\
\hline & & Y.3 & 0,743 & Valid \\
\hline & & Y.4 & 0,774 & Valid \\
\hline & & Y.5 & 0,715 & Valid \\
\hline
\end{tabular}

Sumber: Data diolah, 2017 
ISSN: 2302-8556

E-Jurnal Akuntansi Universitas Udayana

Vol.22.2. Februari (2018): 1503-1529

Berdasarkan Tabel 5 menunjukkan bahwa instrumen penelitian yang terdiri dari item-item pernyataan pengetahuan perpajakan (X1), kesadaran (X2), pengetahuan tax amnesty (X3), dan kepatuhan wajib pajak (Y) memiliki nilai koefisien korelasi yang lebih besar dari 0,30 . Jadi, seluruh indikator pernyataan tersebut telah memenuhi syarat validitas data

Menurut Ghozali (2013:47) reliabilitas adalah alat untuk mengukur suatu kuesioner yang merupakan indikator dari variabel atau konstruk. Suatu instrumen dikatakan reliabel jika suatu pengukuran dapat memberikan hasil yang konsisten atau stabil dari waktu ke waktu. Pengujian validitas ini menggunakan uji statisik Cronbach Alpha. Instrumen dikatakan reliabel jika nilai Cronbach Alpha lebih besar dari 0,70. Hasil uji reliabilitas dapat dilihat pada Tabel 6.

Tabel 6. Hasil Uji Reliabilitas

\begin{tabular}{clcc}
\hline No & \multicolumn{1}{c}{ Variabel } & Cronbach's Alpha & Keterangan \\
\hline 1 & Pengetahuan Perpajakan (X1) & 0,824 & Reliabel \\
2 & Kesadaran (X2) & 0,803 & Reliabel \\
3 & Pengetahuan Tax Amnesty (X3) & 0,826 & Reliabel \\
4 & Kepathua Wajib Pajak (Y) & 0,809 & Reliabel \\
\hline Sumber: Data diolah, 2017
\end{tabular}

Berdasarkan Tabel 6 menunjukkan bahwa nilai cronbach alpha masingmasing variabel memiliki nilai lebih besar dari 0,70. Sehingga dapat disimpulkan bahwa pernyataan dalam kuesioner penelitian ini reliabel dan dapat digunakan.

Uji normalitas bertujuan untuk mengetahui apakah variabel residualnya memiliki distribusi normal atau tidak (Ghozali, 2013:160). Pengujian ini 
menggunakan uji statistik non-parametrik Kolmogorov-Smirnov. Residual berdistribusi normal apabila Asymp. Sig lebih besar dari $\alpha(0,05)$. Hasil uji normalitas dapat dilihat pada Tabel 7.

Tabel 7.

Hasil Uji Normalitas

\begin{tabular}{lr}
\hline & Unstandardized Residual \\
\hline $\mathrm{N}$ & 100 \\
Asymp. Sig. (2-tailed) & 0,995 \\
\hline Sumber: Data diolah, 2017
\end{tabular}

Berdasarkan Tabel 7 menunjukkan bahwa unstandardized residual memiliki nilai asymp. sig. (2-tailed) sebesar 0,995 yang lebih besar dari taraf signifikansi 0,05. Hal ini berarti seluruh data berdistribusi normal.

Uji multikolinieritas bertujuan untuk mengetahui adanya korelasi antar variabel bebas pada model regresi. Model regresi yang baik seharusnya tidak terjadi korelasi diantara variabel bebasnya. Pengujian multikolonieritas dapat dilihat dari nilai tolerance dan nilai variance inflation factor (VIF). Model regresi yang bebas dari multikolinearitas, jika nilai tolerance $>10 \%$ atau VIF $<10$ (Ghozali, 2013: 105). Hasil uji multikolinearitas dapat dilihat pada Tabel 8.

Tabel 8.

Hasil Uji Multikolinearitas

\begin{tabular}{lccc}
\hline \multicolumn{1}{c}{ Variabel } & \multicolumn{2}{c}{ Collinearity Statistic } & \multirow{2}{*}{ Keterangan } \\
& Tolerance & VIF & Bebas Multikoleniaritas \\
\hline Pengetahuan Perpajakan (X1) & 0,734 & 1,363 & Bebas Multikoleniaritas \\
Kesadaran (X2) & 0,258 & 3,876 & Bebas Multikoleniaritas \\
Pengetahuan Tax Amnesty & 0,230 & 4,352 & \\
(X3) & &
\end{tabular}

Sumber: Data diolah, 2017 
ISSN: 2302-8556

E-Jurnal Akuntansi Universitas Udayana

Vol.22.2. Februari (2018): 1503-1529

Berdasarkan Tabel 8 dapat dilihat bahwa hasil uji mulkolinearitas menunjukkan bahwa masing-masing variabel bebas memiliki nilai tolerance lebih besar dari 0,10 dan nilai VIF lebih kecil dari 10. Maka dapat disimpulkan bahwa tidak ada multikolinearitas antar variabel bebas dalam model regresi.

Pengujian heteroskedastisitas dilakukan untuk mengetahui apakah dalam model regresi terjadi ketidaksamaan variance dari residual satu pengamatan ke pengamatan yang lain dalam model regresi (Ghozali, 2013: 139). Model regresi yang baik adalah tidak terjadinya heteroskedastisitas atau variance yang homogen. Untuk mendeteksi ada atau tidak adanya heteroskedastisitas digunakan analisis dengan uji glejser. Jika tingkat signifikansi berada di atas 0,05 maka tidak terjadi heteroskedastisitas dalam model regresi. Hasil uji heteroskedastisita dapat dilihat pada Tabel 9.

Tabel 9.

Hasil Uji Heteroskedastisitas

\begin{tabular}{lcc}
\hline \multicolumn{1}{c}{ Variabel } & Sig. & Keterangan \\
\hline Pengetahuan Perpajakan (X1) & 0,812 & Bebas Heteroskedastisitas \\
Kesadaran (X2) & 0,053 & Bebas Heteroskedastisitas \\
Pengetahuan Tax Amnesty (X3) & 0,120 & Bebas Heteroskedastisitas \\
\hline Sumber: Data diolah, 2017 & &
\end{tabular}

Berdasarkan Tabel 9 menunjukkan bahwa nilai signifikansi masing-masing variabel diatas 0,05 . Jadi, dapat disimpulkan bahwa model regresi dalam penelitian ini bebas dari gejala heteroskedastisitas. 
Analisis regresi linear berganda digunakan untuk memecahkan rumusan masalah yang ada, yaitu untuk melihat pengaruh antara dua variabel atau lebih. Hasil analisis regresi linear berganda dapat dilihat pada Tabel 10.

Tabel 10.

Hasil Analisis Regresi Linear Berganda

\begin{tabular}{|c|c|c|c|c|c|}
\hline \multirow[t]{2}{*}{ Variabel } & \multicolumn{2}{|c|}{$\begin{array}{c}\text { Unstandardized } \\
\text { Coefficients }\end{array}$} & \multirow{2}{*}{$\begin{array}{c}\begin{array}{c}\text { Standardized } \\
\text { Coefficients }\end{array} \\
\text { Beta }\end{array}$} & \multirow{2}{*}{$\mathbf{t}$} & \multirow{2}{*}{ Sig. } \\
\hline & B & $\begin{array}{c}\text { Std. } \\
\text { Error }\end{array}$ & & & \\
\hline (Constant) & 1,187 & 1,045 & & 1,136 & 0,259 \\
\hline $\begin{array}{l}\text { Pengetahuan Perpajakan } \\
\text { (X1) }\end{array}$ & 0,303 & 0,055 & 0,309 & 5,507 & 0,000 \\
\hline Kesadaran (X2) & 0,366 & 0,094 & 0,367 & 3,873 & 0,000 \\
\hline $\begin{array}{l}\text { Pengetahuan Tax Amnesty } \\
\text { (X3) }\end{array}$ & 0,331 & 0,095 & 0,348 & 3,470 & 0,001 \\
\hline $\begin{array}{l}\text { Adjusted } R^{2} \\
\mathrm{~F}\end{array}$ & & & & & $\begin{array}{r}0,771 \\
111,867\end{array}$ \\
\hline Sig. F & & & & & 0,000 \\
\hline
\end{tabular}

Berdasarkan Tabel 10 persamaan regresi sebagai berikut:

$Y=1,187+0,303\left(X_{1}\right)+0,366\left(X_{2}\right)+0,331\left(X_{3}\right)$

Berdasarkan Tabel 10 nilai konstanta $(\alpha)$ sebesar 1,187 apabila pengetahuan perpajakan $\left(\mathrm{X}_{1}\right)$, kesadaran $\left(\mathrm{X}_{2}\right)$, dan pengetahuan tax amnesty $\left(\mathrm{X}_{3}\right)$ sama dengan nol, maka kepatuhan wajib pajak (Y) meningkat sebesar 1,187. Nilai koefisien $\left(\beta_{1}\right)$ sebesar 0,303 menunjukkan apabila pengetahuan perpajakan $\left(X_{1}\right)$ mengalami peningkatan, maka kepatuhan wajib pajak akan cenderung meningkat. Ini berarti semakin besar pengetahuan perpajakan yang dimiliki, maka wajib pajak akan semakin patuh dalam memenuhi kewajiban perpajakannya. Nilai koefisien $\left(\beta_{2}\right)$ sebesar 0,366 menunjukkan apabila kesadaran $\left(X_{2}\right)$ mengalami peningkatan, 
ISSN: 2302-8556

E-Jurnal Akuntansi Universitas Udayana

Vol.22.2. Februari (2018): 1503-1529

maka kepatuhan wajib pajak akan cenderung meningkat. Ini berarti semakin besar kesadaran yang dimiliki, maka wajib pajak akan semakin patuh dalam memenuhi kewajiban perpajakannya. Nilai koefisien $\left(\beta_{3}\right)$ sebesar 0,331 menunjukkan apabila pengetahuan tax amnesty $\left(\mathrm{X}_{3}\right)$ mengalami peningkatan, maka kepatuhan wajib pajak akan cenderung meningkat. Ini berarti semakin besar pengetahuan tax amnesty yang dimiliki, maka wajib pajak akan semakin patuh dalam memenuhi kewajiban perpajakannya.

Koefisien Determinasi $\left(\mathrm{R}^{2}\right)$ digunakan untuk mengukur seberapa jauh kemampuan model dalam menerangkan variasi variabel dependen. Nilai $\mathbb{R}^{2}$ yang kecil berarti kemampuan variabel-variabel independen dalam menjelaskan variasi variabel independen amat terbatas, sedangkan apabila nilai koefisien determinasi tinggi berarti variabel independen mampu sepenuhnya menjelaskan variasi dari variabel dependen.

Tabel 10 menunjukkan bahwa nilai Adjusted $\mathrm{R}^{2}$ sebesar 0,771 memiliki arti bahwa $77,1 \%$ variabel kepatuhan wajib pajak dipengaruhi oleh pengetahuan perpajakan, kesadaran, dan pengetahuan tax amnesty, sedangkan sisanya 22,9\% dijelaskan oleh faktor lainnya yang tidak terdapat dalam penelitian ini.

Pengujian ini dilakukan untuk mengetahui apakah variabel independen yang digunakan bersifat layak digunakan atau tidak sebagai variabel penjelas atau prediktor. Berdasarkan Tabel 10 menujukkan bahwa nilai signifikansi $\mathrm{F}$ adalah 
sebesar 0,000 yang lebih kecil dari 5 persen. Hal ini berarti model dalam penelitian ini layak digunakan (fit).

Hal ini menunjukkan bahwa hipotesis pertama dalam penelitian ini diterima yaitu, pengetahuan perpajakan berpengaruh positif pada kepatuhan wajib pajak orang pribadi di Kantor Pelayanan Pajak Pratama Gianyar.

Pengetahuan sangat penting dalam membantu wajib pajak dalam melaksanakan kewajibannya. Seorang wajib pajak harus terlebih dahulu mengetahui apa yang menjadi kewajibannya. Semakin banyaknya pengetahuan perpajakan yang diketahui oleh wajib pajak maka semakin tinggi kesadaran yang dimiliki wajib pajak sehingga dapat meningkatkan kepatuhan wajib pajak dalam memenuhi kewajiban perpajakannya, sebaliknya jika semakin sedikit pengetahuan perpajakan yang diperoleh wajib pajak maka semakin rendah tingkat kepatuhan wajib pajak dalam memenuhi kewajiban perpajakannya.

Hal ini menunjukkan bahwa hipotesis kedua dalam penelitian ini diterima yaitu, kesadaran berpengaruh positif pada kepatuhan wajib pajak orang pribadi di Kantor Pelayanan Pajak Pratama Gianyar. Kesadaran wajib pajak dalam membayar kewajibannya merupakan hal penting dalam penerimaan pajak. Peningkatan penerimaan pajak negara akan terjadi jika adanya kesadaran wajib pajak akan peraturan perpajakan dan kewajiban pajaknya. Maka dapat dinyatakan bahwa semakin besar kesadaran yang dimiliki, maka wajib pajak akan semakin patuh dalam memenuhi kewajiban perpajakannya. Sebaliknya jika semakin rendah kesadaran yang dimiliki wajib pajak, maka semakin rendah pula kepatuhan wajib pajak dalam 
ISSN: 2302-8556

E-Jurnal Akuntansi Universitas Udayana

Vol.22.2. Februari (2018): 1503-1529

memenuhi kewajiban perpajakannya. Hal ini menunjukkan bahwa hipotesis ketiga dalam penelitian ini diterima yaitu, pengetahuan tax amnesty berpengaruh positif pada kepatuhan wajib pajak orang pribadi di Kantor Pelayanan Pajak Pratama Gianyar.

Tax Amnesty merupakan salah satu kebijakan dibidang perpajakan yang dilaksanakan oleh Dirjen Pajak. Pengetahuan Tax Amnesty juga diperlukan untuk menambah pengetahuan terhadap kepatuhan wajib pajak mengikuti tax amnesty. Semakin banyaknya pengetahuan tax amnesty yang diketahui oleh wajib pajak, maka semakin tinggi kesadaran yang dimiliki wajib pajak sehingga dapat meningkatkan kepatuhan wajib pajak dalam memenuhi kewajiban perpajakannya. Sebaliknya jika semakin rendah pengetahuan tax amnesty yang dimiliki wajib pajak, maka semakin rendah pula kesadaran wajib pajak sehingga dapat menurunkan kepatuhan wajib pajak dalam memenuhi kewajiban perpajakannya.

\section{SIMPULAN}

Simpulan yang dapat diambil berdasarkan hasil analisis dan pembahasan dalam penelitian ini adalah Pengetahuan Perpajakan berpengaruh positif pada kepatuhan wajib pajak orang pribadi. Semakin besar tingkat pengetahuan perpajakan, maka semakin besar pula kepatuhan wajib pajak orang pribadi. Selanjutnya Kesadaran berpengaruh positif pada kepatuhan wajib pajak orang pribadi. Semakin besar tingkat kesadaran, maka semakin besar pula kepatuhan wajib pajak orang pribadi dan pengetahuan Tax Amnesty berpengaruh positif pada kepatuhan wajib pajak orang 
pribadi. Semakin besar tingkat pengetahuan tax amnesty, maka semakin besar pula kepatuhan wajib pajak orang pribadi.

Saran yang dapat diberikan dalam penelitian ini adalah bagi peneliti selanjutnya jika tertarik dengan topik ini, sebaiknya menggunakan lokasi penelitian lain dan memperluas wilayah pengambilan sampel untuk mengetahui tingkat kepatuhan wajib pajak di wilayah atau ruang lingkup yang berbeda. Sedangkan bagi pemerintah harus tetap mengawasi dan menjaga perbaikan peraturan perpajakan yang ada di Indonesia. Diharapkan nantinya target yang sudah ditetapkan oleh pemerintah bisa tercapai dan meningkat dari tahun sebelumnya dan meningkatkan pengetahuan perpajakan, kesadaran, dan pengetahun tax amnesty dari wajib pajak dalam meningkatkan kepatuhan wajib pajak pada Kantor Pelayanan Pajak Pratama Gianyar, sebaiknya terus dilakukan sosialisasi kepada masyarakat secara rutin. Sebagai upaya meningkatkan pengetahuan wajib pajak melalui pemberian seminar, pelatihan, serta mengkaji kembali peraturan perpajakan dimana diharapkan mempermudah wajib pajak mempelajari perpajakan. Sosialisasi juga dapat menambah pemahaman diri wajib pajak terhadap peraturan perpajakan dan dapat membantu meningkatkan sikap sadar masyarakat mau untuk membayar pajak dan memenuhi kewajiban perpajakannya.

\section{REFERENSI}

Andreoni, James. 1991. The Desirability of a Permanent Tax Amnesty. Journal of Public Economics, Vol. 45: 143-159.

Alm, James. 1998. "Tax Policy Analysis: the Introduction of a Russian Tax Amnesty." International Studies Program Working Paper 98-6. Georgia: 
ISSN: 2302-8556

E-Jurnal Akuntansi Universitas Udayana

Vol.22.2. Februari (2018): 1503-1529

Georgia State University Andrew Young School of Policy Studies.

Ali et al. 2001. The Effects of Tax Rates And Enforcement Polices On Tax Payer Compliance: A study of Self-Employed Tax Payers. Antlantic economic journal, 29(2).

Agung Mas Andriani Pratiwi, I G.A.M. 2014. Pengaruh Kesadaran Wajib Pajak, Kualitas Pelayanan, Kondisi Keuangan Perusahaan, Dan Persepsi Tentang Sanksi Perpajakan Pada Kepatuhan Wajib Pajak Reklame Di Dinas Pendapatan Kota Denpasar. E-Jurnal Akuntansi Universitas Udayana. Vol 6(1), h:139-153.

Arum, Harjanti Puspa. 2012. Pengaruh Kesadaran Wajib Pajak, Pelayanan Fiskus, dan Sanksi Pajak Terhadap Kepatuhan Wajib Pajak Orang Pribadi Yang Melakukan Kegiatan Usaha Dan Pekerjaan Bebas (Studi di Wilayah KPP Pratama Cilacap). E-Jurnal Universitas Diponegoro Semarang. Vol 1(1), h.1-8.

Banu Witono. 2008. Peran Pengetahuan Pajak Pada Kepatuhan Wajib Pajak. Jurnal Akuntansi dan Keuangan, Vol 7. No. 2.

Darussalam, Danny. 2011. Mendongkrak pajak dari underground economy. Investor dail, Edisi 21.

Direktorat Jendral Pajak, 2007, Undang-Undang Republik Indonesia Nomor 28 Tahun 2007 tentang Perubahan Ketiga Atas Undang-Undang Republik Indonesia Nomor 6 Tahun 1983 tentang Ketentuan Umum dan Tata Cara Perpajakan. Jakarta: Penerbit Buku Berita Pajak.

Direktorat Jenderal Pajak. (2016). http://www.pajak.go.id/amnestipajak. Diakses 30 Juni 2017.

Ghozali, Imam. 2013. Aplikasi Analisis Multivariate dengan Program IMB SPSS 23 Update PLS Regresi. Semarang : Badan Penerbit Universitas Diponogoro.

Gunawan, Andri \& I Made Sukartha. 2016. Pengaruh Persepsitax Amnesty, Pertumbuhan Ekonomi dan Transformasi Kelembagaan Direktorat Jenderal Pajak Pada Penerimaan Pajak. E-Jurnal Akuntansi Universitas Udayana. Vol 17(3), h: 2036-2060. 
Hardiningsih, Pancawati dan Nila Yulianawati. 2011. Faktor-Faktor Yang Mempengaruhi Kemauan Membayar Pajak. Dinamika Keuangan dan Perbankan. Vol. 3, No. 1. Hal. 126-142.

James Alm, Jorge Martinez-Vazquez, and Sally Wallace. 2009. Do Tax Amnesties Work? The Revenue Effects of Tax Amnesties During the Transition in the Russian Federation. Department of Economics, Andrew Young School of Policy Studies, Georgia State University, Atlanta, Georgia 30302-3992, USA.

Kanghua Zeng, Shan Li, Qian Li. 2013. The Impact of Economic Growth and Tax Reform on Tax Revenue and Structure: Evidence from China Experience. Modern Economy, 4, 839-851.

Kementrian Keuangan Republik Indonesia. Realisasi Penerimaan Negara (Triliun Rupiah), Tahun 2012-2016. http://www.kemenkeu.go.id. Diakses 7 Juli 2017.

Lovihan, Siska. 2014. Pengaruh Kesadaran Membayar Pajak, Pengetahuan dan Pemahaman Peraturan Perpajakan, dan Kualitas Layanan terhadap Kemauan Membayar Pajak Wajib Orang Pribadi di Kota Tomohon. Jurnal Riset Akuntansi dan Auditing "Goodwill”, Vol.5 No.1.

Muliari, Ni Ketut dan Putu Ery Setiawan. 2009. Pengaruh Persepsi Tentang Sanksi Perpajakan Dan Kesadaran Wajib Pajak Pada Kepatuhan Pelaporan Wajib Pajak Orang Pribadi Di Kantor Pelayanan Pajak Pratama Denpasar Timur. Jurnal Akuntansi dan Bisnis.

Munari. 2005. Pengaruh Faktor Tax Payer Terhadap Keberhasilan Penerimaan PPH. Jurnal Eksekutif, Vol. 2, No. 2.

Ngadiman dan D. Huslin. 2015. Pengaruh Sunset Policy, Tax Amnesty, dan Sanksi Pajak terhadap Kepatuhan Wajib Pajak (Studi Empiris di Kantor Pelayanan Pajak Pratama Jakarta Kembangan). Jurnal Akuntansi 19(2): 225-241.

Noor Sharoja Sapiei dan Jeyapalan Kasipillai. 2013. Impacts of the Self-Assessment System for Corporate Taxpayers. American Journal of Economics 2013, 3(2): 75-81 DOI: 10.5923/j.economics.20130302.03.

Nugroho, Agus. 2005. Strategi Jitu : Memilih Metode Statistik Penelitian dengan SPSS. Yogyakarta: Andi. 
ISSN: 2302-8556

E-Jurnal Akuntansi Universitas Udayana

Vol.22.2. Februari (2018): 1503-1529

Palil, Mohd. Rizal. 2005. Taxpayers Knowledge: A Descriptive Evidence on Demographic Factors in Malaysia. Jurnal Akuntansi dan Keuangan. Vol 7(1) : Hal. 11-21.

Palil, M. Rizal dan Ahmad Faric Mustapha. 2011. Factors affecting tax compliance behavior in self assessment system. African Journal of Business Management, 5(55), p: 12864-12872.

Putri, Christella Pradista Riyana. 2015. Analisis Pengaruh Kesadaran Wajib Pajak, Pengetahuan Perpajakan, Sosialisasi Perpajakan dan Pelayanan Fiskus Terhadap Kepatuhan Wajib Pajak Hotel Melati Di Kota Yogyakarta. Jurnal. Universitas Atma Jaya Yogyakarta.

Rahyuda, I Ketut dkk. 2004. Metodologi Penelitian. Fakultas Ekonomi Universitas Udayana, Denpasar.

Rahayu, Nurulita. 2017. Pengaruh Pengetahuan Perpajakan, Ketegasan Sanksi Pajak, dan Tax Amnesty Terhadap Kepatuhan Wajib Pajak. Jurnal Akuntansi. Vol 1(1):p:2550-0376.

Supadmi. 2010. Meningkatkan Kepatuhan Wajib Pajak Melalui Kualitas. Jurnal Akuntansi dan Bisnis : Fakultas Ekonomi Universitas Udayana.

Suryadi. 2006. Model Hubungan Kausal Kesadaran, Pelayanan, Kepatuhan Wajib Pajak dan Pengaruhnya Terhadap Kinerja Penerimaan Pajak: Suatu Survei di Wilayah Jawa Timur. Jurnal Keuangan Publik. Vol 4 (1) : Hal. 105-121

Sugiyono. 2017. Metode Penelitian Kuantitatif, Kualitatif Dan R\&D. Bandung: Alfabeta.

Suyanto. 2016. Tax Amnesty. Jurnal Akuntansi VOL.4 NO. 2 Desember 2016.

Ulfa, Istika Herliani. 2015. Pengaruh Kesadaran, Pengetahuan Pajak dan Sikap Wajib Pajak Terhadap Kepatuhan Wajib Pajak Pekerjaan Bebas Di Kpp Pratama Semarang Timur. Jurnal Akuntansi. Universitas Dian Nuswantoro.

Undang-Undang Republik Indonesia Nomor 28 Tahun 2007 tentang Ketentuan Umum dan Tata Cara Perpajakan. Jakarta: Penerbit Buku Berita pajak.

Undang-Undang Republik Indonesia No 11 Tahun 2016 Tentang Pengampunan Pajak. 